\title{
Habitat colonisation by amphipods: Comparison between native and alien algae
}

\author{
Maite Vázquez-Luis a,b,*, Joseph A. Borg ${ }^{\text { }}$, Pablo Sanchez-Jerez ${ }^{\text {, }}$, Just T. Bayle-Sempere ${ }^{\mathrm{d}}$ \\ a Centro de Investigación Marina de Santa Pola (CIMAR), Ayto. de Santa Pola y Universidad de Alicante, Torre d'Enmig s/n, Cabo de Santa Pola, Alicante, Spain \\ ${ }^{\mathrm{b}}$ Instituto Español de Oceanografía, Centre Oceanogràfic de les Balears, Moll de Ponent s/n, 07015 Palma de Mallorca, Spain \\ c Department of Biology, Faculty of Science, University of Malta, Msida MSD2080, Malta \\ d Departamento de Ciencias del Mar y Biología Aplicada, Edificio Ciencias V. Universidad de Alicante, POB. 99, E-03080 Alicante, Spain
}

\section{A R T I C L E I N F O}

Article history:

Received 28 February 2012

Received in revised form 16 July 2012

Accepted 22 July 2012

Available online $\mathrm{xxxx}$

\section{Keywords:}

Biological invasion

Caulerpa racemosa

Ecological consequences

Field experiments

Mediterranean Sea

Trophic flows

\begin{abstract}
A B S T R A C T
Invasion of algal habitat by the alien alga Caulerpa racemosa results in changes to habitat structure, part of which may be due to accumulation of large amounts of detritus. In turn, such changes lead to alterations in the assemblage structure of associated invertebrates. The present study was aimed at testing the hypotheses that (i) invasion by C. racemosa will influence the assemblage structure of amphipods associated with vegetated habitats, since colonisation by the invertebrates will differ between native algal habitat and habitat invaded by the alien alga, and (ii) differences in colonisation are mainly due to accumulation of detritus by the alien alga. To test these hypotheses, field experiments on habitat colonisation were undertaken at two sites within each of two Mediterranean localities (Malta and Spain). Using mesh bags, 3 different habitats were introduced at each site: habitat with the native alga Halopteris scoparia, habitat with C. racemosa, and an artificial habitat resembling algal habitat. Additionally, empty mesh bags were deployed as controls. Mesh bags containing plant material were defaunated prior to deployment. For each of the three habitat types, three supplement treatments were used: (i) no detritus, (ii) low detritus, and (ii) high detritus. The bags were placed on a rocky substratum at a water depth of $4.5-5 \mathrm{~m}$ for a period of 14 days, after which they were collected and the amphipod assemblage was assessed. The results showed that, overall, amphipod species richness and abundance were higher in bags containing $H$. scoparia but some amphipods exhibited a broad capability to colonize new habitat such as C. racemosa. Accumulation of detritus by the alien alga may play an important role but small-scale physical or biological habitat features can affect its ecological role.
\end{abstract}

Published by Elsevier B.V

\section{Introduction}

On shallow marine rocky bottoms, macrophytes are the most important organisms that contribute to habitat structural complexity and heterogeneity. Macrophytes act as ecosystem engineers by creating or modifying a habitat (Crooks, 2002). Several effects of habitat complexity on benthic ecosystems are recognised; two important ones being (i) habitat heterogeneity or patchiness of habitat across a landscape and (ii) habitat structure-the physical architectural component that contributes to complexity (Sebens, 1991). In general, Mediterranean rocky bottom algal habitats occur in mosaics and patches in which different algal species are spatially aggregated at various spatial scales. Habitat complexity differs between algal stands formed by different species and is influenced by factors such as whether the algae are encrusting or erect, tall or low lying (turf), or if they support epiphytes. Hence, algal habitats can be very heterogeneous such that the availability of habitat/microhabitat space for colonisation by other species varies greatly.

\footnotetext{
* Corresponding author at: Centro de Investigación Marina de Santa Pola (CIMAR), Ayto. de Santa Pola y Universidad de Alicante, Torre d'Enmig s/n, Cabo de Santa Pola, Alicante, Spain.

E-mail address: MT.Vazquez@ua.es (M. Vázquez-Luis).
}

Invasive marine algae can modify habitat structure and, consequently, result in large ecological effects (see review in Williams and Smith, 2007). The number of introduced species outside their natural ranges is rapidly increasing, although a relatively small proportion of transported and introduced species become invasive (Williamson and Fitter, 1996). However, the ability of such species to restructure and, hence, radically change the functioning of the recipient habitat is high (Crooks, 2002). Invasive species may (i) modify the availability and flow of nutrients in an ecosystem by altering biogeochemical cycling; (ii) contribute to changes in energy flow through a food web; and (iii) affect the availability or quality of resources, including the physical and chemical characteristics of a habitat such as available space, sediment properties, light regime and water quality (see Crooks, 2002; Vitousek, 1990). Frequently, an invasive species acts as an ecosystem engineer, hence influencing the biota that will become associated with the habitat. When this occurs, the resulting community will have mixed characteristics that are attributed to the initial pool of species and habitat preferences and to the colonization rate of the invasive species.

Amphipods are one of the most ubiquitous and abundant invertebrate groups in marine vegetated habitats, with densities often reaching several thousand individuals per square meter (Brawley, 1992; Vázquez-Luis 
et al., 2008). They are important secondary producers (Carrasco and Arcos, 1984; Highsmith and Coyle, 1990; Sarvala and Uitto, 1991) and serve as food for a large variety of marine fauna (Beare and Moore, 1997; Sanchez-Jerez et al., 1999; Stål et al., 2007; Stoner, 1979), hence playing a key role in energy flow through food webs (Vázquez-Luis et al., 2010). Amphipods respond to habitat modification (Vázquez-Luis et al., 2008, 2009b); some species exhibit high habitat specificity, while others tolerate a range of habitat alteration that may result from pollution, invasion by alien species, and other disturbances, and can therefore be used as an indicator of disturbance of vegetated habitat (Bellan-Santini, 1980; Conradi et al., 1997; Sanchez-Jerez et al., 2000; Virnstein, 1987).

In the Mediterranean Sea, concerns on the appearance of the alien alga Caulerpa racemosa var. cylindracea (hereafter $C$. racemosa) have resulted in several studies on the ecology of this species (see Cavas et al., 2006; Ruitton et al., 2005). A main concern is that the fauna associated with native vegetation can change with the introduction of exotic algae (Schmidt and Scheibling, 2007; Wikström and Kautsky, 2004). As a result, several works have been focussed on assessing potential changes in the faunal assemblages associated with Mediterranean vegetated habitats when these are colonised by $C$. racemosa (Argyrou et al., 1999; Piazzi and Balata, 2008; Vázquez-Luis et al., 2008, 2009a,b). Results of previous studies on Mediterranean shallow rocky habitat indicated that the presence and amount of $C$. racemosa led to marked effects on the native macroalgal assemblage structure by affecting macrophyte species composition and biomass since the alien alga forms homogeneous monospecific stands in which detritus accumulates (Vázquez-Luis et al., 2008, 2009b). Such effects, brought about by changes to the structural complexity and to other physical attributes of the native algal habitat following invasion by C. racemosa, are reflected in the species composition, assemblage structure, and trophic dynamics of the associated amphipod assemblages (see Fig. 1). As a result, the amphipod assemblages associated with $C$. racemosa differ from those associated with native seaweeds; in addition to recorded differences in amphipod abundance and species richness, results also show an increased abundance of detritivorous species and a decrease of herbivorous species. Furthermore, the presence of $C$. racemosa may affect the flow of matter and energy from invertebrates to higher trophic levels (Vázquez-Luis et al., 2010).

Studies on the ecology of macrofauna associated with $C$. racemosa stands have been mainly focussed on post-invasion assessment, while there is a dearth of data on the situation before invasion by the alien alga compared to that following invasion. The present study was aimed at testing the hypotheses that (i) invasion by C. racemosa will influence the assemblage structure of amphipods associated with vegetated habitats, since colonisation by the invertebrates will differ between native algal habitat and habitat invaded by the alien alga, and (ii) differences in colonisation are mainly due to accumulation of detritus by the alien alga. To test these hypotheses, we undertook colonisation experiments in the field, which were preceded by characterisation of the amphipod fauna associated with natural habitat at the study sites to enable comparison with the amphipod assemblages following colonisation of experimental units. Our experiments were replicated in two Mediterranean localities, separated by thousands of kilometres, to assess whether the same patterns occurred consistently over a large spatial scale.

\section{Materials and methods}

\subsection{Study sites}

The experiments were carried out in two Mediterranean localities: Malta and Spain. At each locality, two rocky sites with broadly similar environmental characteristics and supporting algal habitat that was not invaded by $C$. racemosa were selected (Fig. 2). The two Maltese sites - Ghallis and Pembroke - are both located on the northeastern coast, while the two Spanish sites - Albir and Sierra Helada - are both located on the Benidorm coast (Alicante), on the eastern coast of Spain. The four sites had similar water depth and habitat characteristics, which comprised a rocky bottom colonised by patchy beds of native algae. At

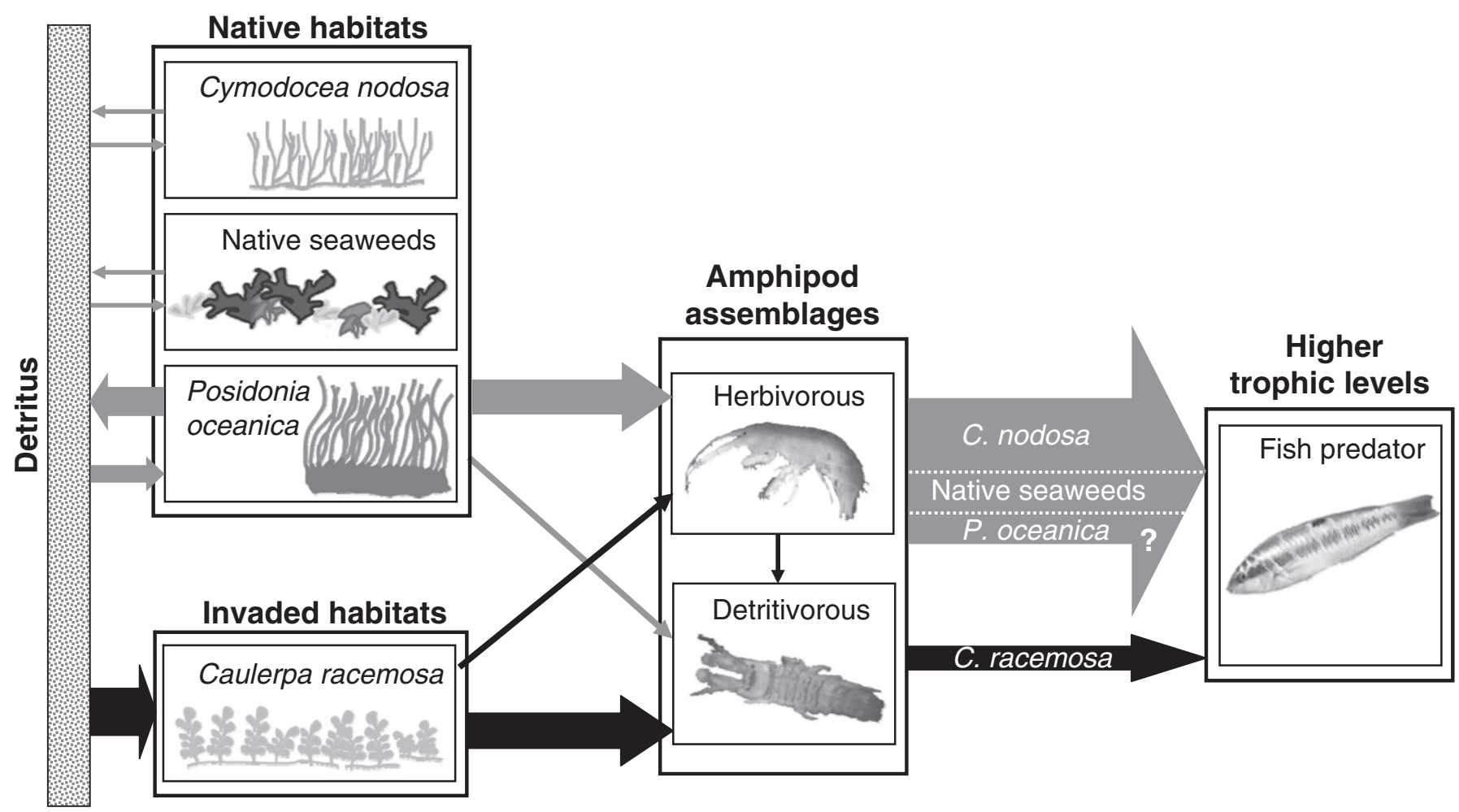

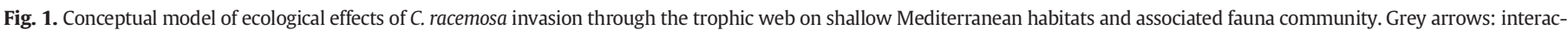
tions by native habitats. Black arrow: interactions by $C$. racemosa invaded habitats. The thickness of the arrows represents the importance of the influence between compartments. 


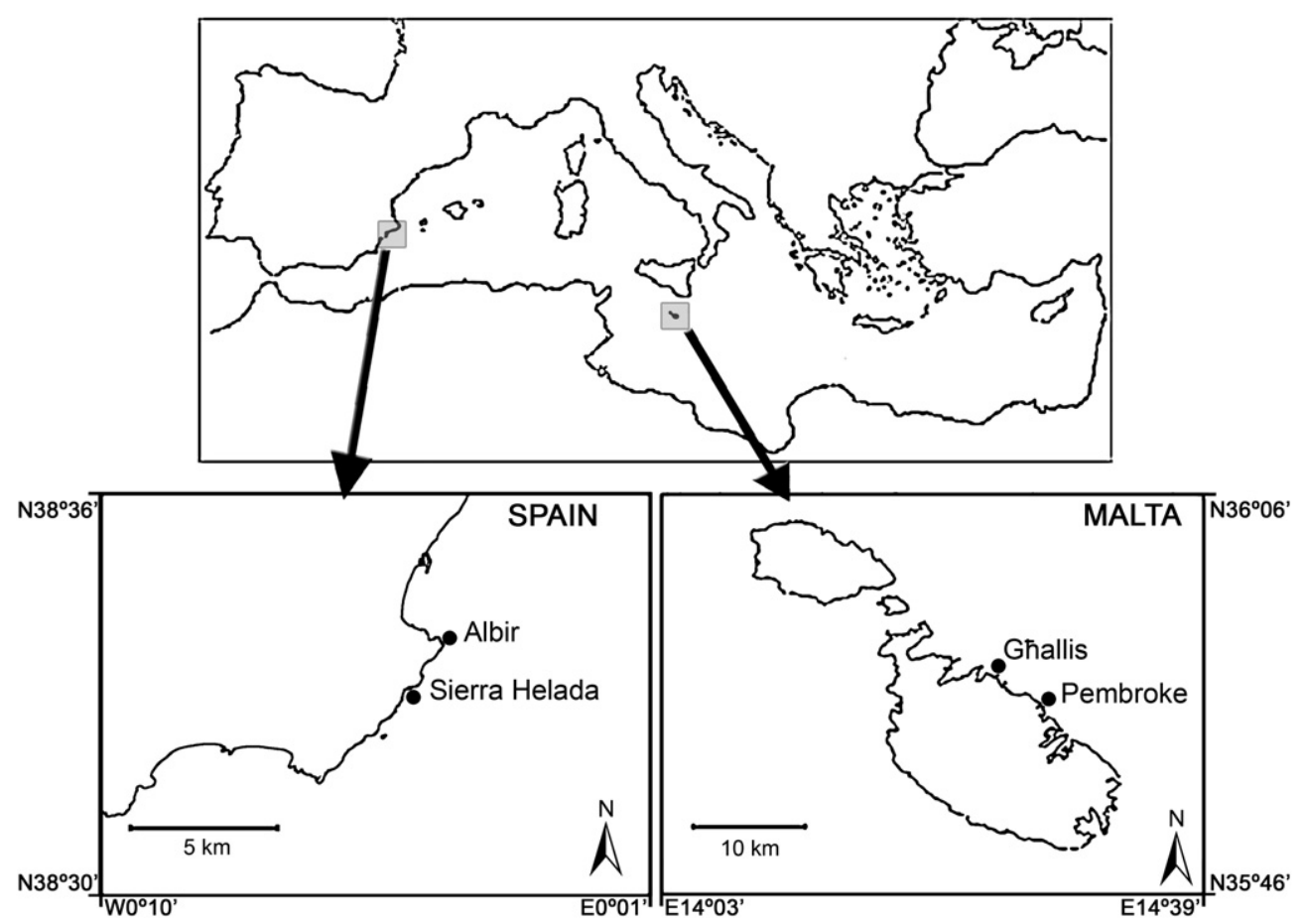

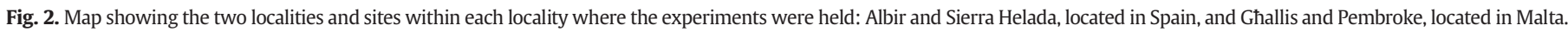

the Maltese sites, the dominant macrophytes were erect phaeophyceae that formed patches with Cystoseira spp., Halopteris scoparia, Cladostephus spongiosus and Dictyopteris polypodioides. Similarly, at the dominant algae at the Spanish sites were erect phaeophyceae, namely H. scoparia accompanied by red turf algae Corallina elongata and Jania rubens.

\subsection{Characterisation of habitat features and amphipod fauna}

To characterise the algae and amphipod fauna at the study sites, three random samples were taken by SCUBA divers at each site using a $20 \times 20 \mathrm{~cm}$ quadrat. Samples were collected by scraping off all the vegetation enclosed by the quadrat. A $300 \mu \mathrm{m}$ mesh net was attached to the quadrat to prevent escape of motile fauna during collection. Samples were preserved in $4 \%$ formalin in seawater. Each replicate was sieved in seawater using a $500 \mu \mathrm{m}$ sieve. In the laboratory, the amphipods were separated, identified and counted. Algae were sorted and identified to species level and dried for $24 \mathrm{~h}$ in an oven at $80{ }^{\circ} \mathrm{C}$ to obtain dry weight.

\subsection{Experimental setup and sampling design}

For the field experiments, two algae were harvested: the native Halopteris scoparia and the alien C. racemosa, which have different habitat structure and complexity characteristics. H. scoparia was selected because it is ubiquitous in shallow water Mediterranean benthic habitats. It is a brown fern-like seaweed that grows to a height of some 20 . In contrast, the invasive $C$. racemosa has slender thalli and is attached to the substratum by means of thin rhizoids that are closely arranged along the stolon.

In the laboratory, the algae were defaunated and their wet weight was recorded. Dry Posidonia oceanica 'balls' (Cannon, 1979) were used as source for the detritus stock. Mesh bags with different treatments (algae and detritus) were then prepared as follows. Bags containing algae ( $H$. scoparia or $C$. racemosa) had a content weighing $80 \mathrm{~g}$ (wet weight) per bag, while those containing 'artificial algae' (synthetic garden shade fabric) had a volume equivalent to that of the algae. Two different treatments were used for bags with detritus: low detritus supplement ( $15 \mathrm{~g}$ wet weight) and high detritus supplement
(50 g wet weight). These detritus weights were chosen on the basis that they are equivalent to the amount of detritus found in habitats colonised by native algae and $C$. racemosa. Accordingly, $15 \mathrm{~g}$ represent around $15 \%$ detritus, which is the typical amount associated with native algae (Vázquez-Luis et al., 2008), while 50 g represent around 40\% detritus, which is the amount typically associated with $C$. racemosa (Vázquez-Luis et al., 2008). Five replicate bags per category/treatment were prepared, such that a total of 120 bags per locality were used.

The initial analysis of variance (ANOVA) design for comparisons had the factors Locality, Habitat, Detritus and Sites. However, due to significant differences in the amphipod assemblages obtained for the factor Locality, separate ANOVAs were carried out for the two localities. Consequently the design was simplified to three factors: (i) 'habitat' ( $\mathrm{Ha})$, which was fixed and had 4 levels: $H$. scoparia, $C$. racemosa, artificial algae and control (only the mesh bag); (ii) 'detritus' (De), which was fixed and orthogonal and had 3 levels (without detritus, low detritus supplement and high detritus supplement); and (iii) 'site' (Si), which was random and orthogonal, and had two levels.

In the field, all bags were deployed randomly at each study site on a rocky bottom supporting algal habitat at a water depth of between $4.5 \mathrm{~m}$ and $5 \mathrm{~m}$. Each bag had a mesh size of $1.6 \mathrm{~cm}$, was $30 \mathrm{~cm}$ long and had a large pebble (collected from a coastal beach) inside to ensure it remained stationary on the seabed. The bag also contained the specific alga/C. racemosa/detritus treatment, and had its upper end closed. Deployment of the mesh nets was made during summer 2008. At each site, the area of seabed over which the mesh bags were spread was around $20 \mathrm{~m}^{2}$. The mesh bags were then collected following 2 weeks from deployment. Immediately following collection of the bags, each one was placed in a plastic bag to avoid escape of macroinvertebrates. In the laboratory, the collected samples were first preserved in $4 \%$ formalin and later sieved through a $500 \mu \mathrm{m}$ mesh sieve to retain the fauna and other material, which was then sorted. All amphipods were identified to species and counted. An index of complexity for the two different algal habitats was calculated as the ratio of surface area to volume (SA/V) for each algal species. This was done by placing the algae flat on graph paper (having graduations in $\mathrm{mm}$ ) and drawing their outline. The area enclosed within the outline was then estimated using the graduations on the paper. 
The volume of the algae was determined using the water displacement method, i.e. using a graduated measuring cylinder. A surface-to-volume ratio (SA/V) is a simple but practical measure of the complexity of biological habitats (Koukouras et al., 1992; Schmidt-Nielson, 1984). H. scoparia had a higher structural complexity compared to C. racemosa $(4.38 \pm 0.06$ and $6.45 \pm 0.19$ respectively, $n=4)$.

\subsection{Data analyses}

For each locality (Malta and Spain), differences in number of species, total abundance of amphipods, and abundance of the most abundant amphipod species were tested using three-factor analysis of variance (ANOVA). Prior to carrying out the ANOVA, the data were tested for heterogeneity of variance using Cochran's C-test. Data were $\sqrt{ } x+1$ or $\log (x+1)$ transformed in cases where the variances were significantly different at $P=0.05$. Where the variance remained heterogeneous following transformation, untransformed data were analysed since ANOVA is a robust statistical test that is relatively unaffected by heterogeneity of variances, particularly in balanced experiments (Underwood, 1997). However, in such cases, special care was taken in the interpretation of results, and to reduce type I error, $\alpha$ was reduced to 0.01 . Where ANOVA indicated a significant difference for a given factor, the source of difference was identified using StudentNewman-Keul (SNK) tests (Underwood, 1981, 1997). Moreover, when the divisor for F-ratio was too small, and statistical differences were not found, pooling was applied for the main factors and interactions.

Non-parametric multidimensional scaling (MDS) was used as the ordination method for exploring differences in the amphipod assemblage composition (Clarke and Warwick, 1994). The similarity matrix, which was calculated using the Bray-Curtis index and using double square transformed data, was used to construct bivariate MDS plots. A permutational multivariate ANOVA (PERMANOVA software, Anderson, 2001) based on the same design used for the univariate analyses was carried out to test for differences in the species composition of the amphipod assemblage. Following the permutational test, a pairwise test was carried out to test differences among groups.

\section{Results}

\subsection{Habitat and amphipod fauna}

A total of 37 amphipod species were recorded from the Maltese sites and 34 from the Spanish ones. At both localities, the abundance of amphipods was high, with values of up to 5000 individuals $\mathrm{m}^{-2}$ being recorded but large differences in values were noted between different sites. In Malta the most abundant species were (in order of decreasing abundance) Elasmopus brasiliensis (602.34 $\pm 152.85 \mathrm{ind} / \mathrm{m}^{2}$ ), Ampithoe ramondi $\left(485.38 \pm 98.06 \mathrm{ind} / \mathrm{m}^{2}\right)$, Dexamine spiniventris $\left(362.57 \pm 89.65 \mathrm{ind} / \mathrm{m}^{2}\right)$, Ericthonius punctatus $\left(347.95 \pm 72.96 \mathrm{ind} / \mathrm{m}^{2}\right)$, Hyale camptonyx $\left(301.17 \pm 104.03 \mathrm{ind} / \mathrm{m}^{2}\right)$ and Cymadusa crassicornis $\left(178.36 \pm 113.01 \mathrm{ind} / \mathrm{m}^{2}\right)$. In Spain, the most abundant species were $A$. ramondi (514.62 $\left.\pm 119.98 \mathrm{ind} / \mathrm{m}^{2}\right)$, Microdeutopus spp. (450.29 \pm 80.61 ind $\left./ \mathrm{m}^{2}\right)$, D. spiniventris $\left(400.58 \pm 236.91 \mathrm{ind} / \mathrm{m}^{2}\right)$, Caprella grandimana $\left(391.81 \pm 190.66 \mathrm{ind} / \mathrm{m}^{2}\right)$, Caprella acanthifera $\left(321.64 \pm 60.38 \mathrm{ind} / \mathrm{m}^{2}\right)$ and Hyale schmidti $\left(201.75 \pm 83.74 \mathrm{ind} / \mathrm{m}^{2}\right)$.

\subsection{Colonisation}

Thirty-four amphipod species colonised the mesh bags in Malta and 33 in Spain. At both localities, species richness was significantly greater in bags containing $H$. scoparia compared to all other treatments (Malta: Ha, $P<0.01$; Table 1, Fig. 3a; Spain: Ha, $P<0.05$; Table 1, Fig. 3b). Total abundance was significantly higher at both localities for bags containing $H$. scoparia (Malta: Ha, $P<0.05$; Table 1 , Fig. $3 c$ and Spain: Ha, $P<0.05$; Table 1, Fig. $3 d$ ); the highest recorded values were for bags having a high content of detritus ( $95.7 \pm 11.22 \mathrm{ind} / \mathrm{bag})$.
No significant differences in total abundance and species richness were detected for the detritus treatment, except for species richness at the Maltese sites where bags having low and high detritus content had a significantly higher number of species (De, $P<0.05$; Table 1 , Fig. 3a). At the Spanish sites, no significant differences were detected for the detritus treatment, but a pattern indicating an increase in amphipod abundance with an increase in the content of detritus was noted.

The two-dimensional MDS plot (Fig. 4) showed grouping of samples mainly by locality. At each locality, samples were grouped mainly by a combination of habitat and detritus content. The obtained multivariate pattern indicated a different response at the two localities (PERMANOVA, LoxHa, $P<0.01$, Table 2). The results of the pairwise test indicated that in Malta the contribution of $H$. scoparia was different between $C$. racemosa and control treatments, which were also different to the contribution of this species to the artificial units. For Spain, the contribution of H. scoparia was different from that of $C$. racemosa, which was different from that of the controls (and similar to the artificial substratum).

The most abundant amphipods recorded from the two study localities were E. brasiliensis, Elasmopus pocillimanus, Gammarella fucicola, C. acanthifera, and Microdeutopus spp., while the abundance of two Lysianassa species, Lysianassa costae and Lysianassa longicornis, differed between the two localities; the former being more abundant in Malta and the latter being more abundant in Spain. Collectively, these species comprised $82 \%$ and $54 \%$ of the amphipod fauna respectively from Malta and Spain. Abundance values of E. brasiliensis were significant higher in H. scoparia habitat in both Malta and Spain (Malta: Ha, $P<0.05$; Table 1, Fig. 5a; Spain: Ha, $P<0.01$; Table 1, Fig. 5b); for the factor 'detritus', the abundance of this species was significantly higher for low and high detritus content at the Maltese sites (De, $P<0.05$; Table 1, Fig. 5a). E. pocillimanus was more abundant in $H$. scoparia bags compared to the other substrata in Spain (Ha, $P<0.05$; Table 1, Fig. $5 \mathrm{f}$ ).

The abundance of $G$. fucicola was high at both Maltese and Spanish sites, but was particularly so in bags containing $H$. scoparia. However, significant differences were detected only for Spain (Ha, $P<0.05$; Table 1 , Fig. 5f). Furthermore, only one site in Malta showed significant differences for high detritus content (DexSi, $P<0.01$; Table 1, Fig. 5e). C. acanthifera had different patterns of abundance at the two study localities: in Malta it was more abundant on $C$. racemosa (Ha, $P<0.05$; Table 1, Fig. $5 g$ ) while in Spain it was more abundant on the artificial substratum at one site (HaxSi, $P<0.05$; Table 1 and Fig. 5 h).

Species of the genus Microdeutopus were, in general, more abundant on H. scoparia and C. racemosa; in Malta, Microdeutopus spp. were significantly more abundant on $C$. racemosa at one site (HaxSi, $P<0.01$; Table 1, Fig. 5i). Furthermore, for bags from Malta, significant differences were found for the factor detritus, with the abundance of Microdeutopus spp. being higher in bags having high detritus content (De, $P<0.05$; Table 1, Fig. 5i). For Spain, significant differences in the abundance of these species were detected for habitat and detritus, but significant differences were recorded for only for one site. The abundance of Microdeutopus spp. was significantly higher on H. scoparia and $C$. racemosa at one of the Spanish sites, and higher on $C$. racemosa at the other site (HaxSi, $P<0.05$; Table 1, Fig. $5 \mathrm{j}$ ). A significant interaction for detritus and site was also indicated for Microdeutopus spp.; at one of the Spanish sites, their abundance was higher in bags having a high content of detritus (DexSi, $P<0.05$; Table 1, Fig. $5 \mathrm{j}$ ), while no differences in abundance were evident at the other site for the different detritus content levels (DexSi, $P<0.05$; Table 1, Fig. 5j). For L. costae in Malta and L. longicornis in Spain the abundance pattern was the same, with the species being more abundant in $\mathrm{H}$. scoparia (Malta: HaxSi, $P<0.01$; Table 1 , Fig. 5k; and Spain: HaxSi, $P<0.05$; Table 1, Fig. 5l).

\section{Discussion}

Overall, both the species richness and abundance of amphipods were higher in bags containing $H$. scoparia. Furthermore, for $C$. racemosa habitat, the results suggest that the presence of detritus results in increased 
Table 1

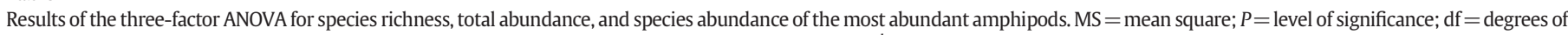
freedom; ns = not significant; ${ }^{*}=$ significant $(P<0.05) ;{ }^{* *}=\operatorname{significant~}(P<0.01) ;{ }^{\mathrm{a}}=$ pooled data HaxSi; ${ }^{\mathrm{b}}=$ pooled data DexSi.

\begin{tabular}{|c|c|c|c|c|c|c|c|c|c|c|}
\hline \multicolumn{11}{|l|}{ Malta } \\
\hline \multirow[t]{2}{*}{ Source of variation } & \multirow[t]{2}{*}{ df } & \multicolumn{2}{|c|}{ Species richness } & \multicolumn{2}{|c|}{ Total abundance } & \multicolumn{2}{|c|}{ Elasmopus brasiliensis } & \multicolumn{2}{|c|}{ Elasmopus pocillimanus } & \multirow[t]{2}{*}{$F$ versus } \\
\hline & & MS & $P$ & MS & $P$ & MS & $P$ & MS & $P$ & \\
\hline Habitat $=\mathrm{Ha}$ & 3 & 91.88 & $0.0001^{* * a}$ & 17746.16 & $0.0221^{*}$ & 42.57 & $0.0259^{*}$ & 12.19 & 0.0516 & $\mathrm{Ha} \times \mathrm{Si}$ \\
\hline Detritus $=\mathrm{De}$ & 2 & 87.06 & $0.0001^{* * \mathrm{~b}}$ & 11781.51 & 0.2333 & 31.1 & $0.0001^{* * \mathrm{~b}}$ & 9.58 & 0.111 & $\mathrm{De} \times \mathrm{Si}$ \\
\hline Site $=\mathrm{Si}$ & 1 & 20.01 & $0.0123^{* a, b}$ & 5057.01 & $0.0013^{* *}$ & 3.48 & $0.0678^{\mathrm{b}}$ & 25.52 & $0.0001^{* *}$ & Res \\
\hline $\mathrm{Ha} \times \mathrm{De}$ & 6 & 5.66 & 0.3700 & 668.13 & 0.3921 & 2.53 & 0.3902 & 1.19 & 0.7662 & $\mathrm{Ha} \times \mathrm{De} \times \mathrm{Si}$ \\
\hline $\mathrm{Ha} \times \mathrm{Si}$ & 3 & 0.69 & 0.8830 & 1053.87 & 0.0827 & 2.83 & $0.0455^{\mathrm{b}}$ & 1.35 & 0.1651 & Res \\
\hline $\mathrm{De} \times \mathrm{Si}$ & 2 & 1.51 & 0.6241 & 3586.01 & $0.0007^{* *}$ & 0.49 & 0.6208 & 1.19 & 0.2192 & Res \\
\hline $\mathrm{Ha} \times \mathrm{De} \times \mathrm{Si}$ & 6 & 4.26 & $0.2275^{\mathrm{a}, \mathrm{b}}$ & 529.07 & 0.3385 & 1.99 & $0.0791^{\mathrm{b}}$ & 2.22 & 0.0133 & Res \\
\hline Residual & 96 & 3.18 & & 459.16 & & 1.03 & & 0.78 & & \\
\hline Cochran's C-test & & $C=0.0$ & & $C=0.162$ & $0.01)$ & $\mathrm{C}=0$. & & $\mathrm{C}=0$. & & \\
\hline Transformation & & - & & - & & $\operatorname{Sqrt}(x$ & & $\operatorname{Ln}(x+$ & & \\
\hline \multirow[t]{2}{*}{ SNK } & & \multirow{2}{*}{\multicolumn{2}{|c|}{$\begin{array}{l}\text { Ha: } \mathrm{H}>\mathrm{Ca}=\mathrm{A}>\mathrm{C} \\
\text { De: } \mathrm{L}=\mathrm{H}>\emptyset\end{array}$}} & \multirow{2}{*}{\multicolumn{2}{|c|}{ Ha: $\mathrm{H}>\mathrm{Ca}=\mathrm{A}=\mathrm{C}$}} & \multirow{2}{*}{\multicolumn{4}{|c|}{$\begin{array}{l}\text { Ha: } H>C a=A=C \\
\text { De: } L=H>\emptyset\end{array}$}} & \\
\hline & & & & & & & & & & \\
\hline \multirow[t]{2}{*}{ Source of variation } & \multirow[t]{2}{*}{ df } & \multicolumn{2}{|c|}{ Gammarella fucicola } & \multicolumn{2}{|c|}{ Caprella acanthifera } & \multicolumn{2}{|c|}{ Microdeutopus spp. } & \multicolumn{2}{|c|}{ Lyssianasa costae } & \multirow[t]{2}{*}{$F$ versus } \\
\hline & & MS & $\boldsymbol{P}$ & MS & $\boldsymbol{P}$ & MS & $\boldsymbol{P}$ & MS & $\boldsymbol{P}$ & \\
\hline Habitat $=\mathrm{Ha}$ & 3 & 25.96 & 0.1024 & 1.31 & $0.0062^{* * a}$ & 1.29 & 0.4595 & 30.79 & 0.3824 & $\mathrm{Ha} \times \mathrm{Si}$ \\
\hline Detritus $=$ De & 2 & 11.14 & 0.5807 & 0.18 & $0.5451^{\mathrm{b}}$ & 1.19 & $0.0143^{* \mathrm{~b}}$ & 4.13 & 0.2832 & $\mathrm{De} \times \mathrm{Si}$ \\
\hline Site $=\mathrm{Si}$ & 1 & 5.29 & 0.1733 & 5.28 & $0.0001^{* * a, b}$ & 4.72 & $0.0001^{* * \mathrm{~b}}$ & 42.01 & $0.0001^{* *}$ & Res \\
\hline $\mathrm{Ha} \times \mathrm{De}$ & 6 & 1.57 & 0.9588 & 0.25 & 0.7638 & 0.1 & 0.6564 & 1.31 & 0.3297 & $\mathrm{Ha} \times \mathrm{De} \times \mathrm{Si}$ \\
\hline $\mathrm{Ha} \times \mathrm{Si}$ & 3 & 4.91 & 0.1623 & 0.07 & 0.8722 & 1.14 & $0.0075^{* * \mathrm{~b}}$ & 21.14 & $0.0001^{* *}$ & Res \\
\hline $\mathrm{De} \times \mathrm{Si}$ & 2 & 15.43 & $0.0055^{* *}$ & 0.05 & 0.8395 & 0.18 & 0.5111 & 1.63 & 0.1409 & Res \\
\hline $\mathrm{Ha} \times \mathrm{De} \times \mathrm{Si}$ & 6 & 7.36 & 0.0213 & 0.46 & $0.1769^{\mathrm{a}, \mathrm{b}}$ & 0.14 & $0.7996^{\mathrm{b}}$ & 0.9 & 0.3669 & Res \\
\hline Residual & 96 & 2.81 & & 0.31 & & 0.27 & & 0.82 & & \\
\hline Cochran's C-test & & $C=0.1$ & & $C=0.109$ & & $\mathrm{C}=0$. & & $C=0$. & $P<0.01)$ & \\
\hline Transformation & & $\operatorname{Sqrt}(x$ & & $\operatorname{Sqrt}(x+1$ & & $\operatorname{Ln}(x+$ & & - & & \\
\hline \multirow[t]{2}{*}{ SNK } & & \multirow{2}{*}{\multicolumn{2}{|c|}{ De $\times$ Si: $2: H>L=\emptyset$}} & \multirow{2}{*}{\multicolumn{2}{|c|}{ Ha: $\mathrm{Ca}>\mathrm{H}=\mathrm{A}=\mathrm{C}$}} & \multicolumn{2}{|c|}{ De: $H>L=\varnothing$} & \multirow{2}{*}{\multicolumn{2}{|c|}{$\begin{array}{l}\mathrm{Ha} \times \mathrm{Si}: 1: \mathrm{H}>\mathrm{Ca}= \\
\mathrm{A}=\mathrm{C}\end{array}$}} & \\
\hline & & & & & & $\begin{array}{l}\mathrm{Ha} \times \mathrm{S} \\
\mathrm{Ca}>\mathrm{H}\end{array}$ & & & & \\
\hline
\end{tabular}

Spain

\begin{tabular}{|c|c|c|c|c|c|c|c|c|c|c|}
\hline \multirow[t]{2}{*}{ Source of variation } & \multirow[t]{2}{*}{ df } & \multicolumn{2}{|c|}{ Species richness } & \multicolumn{2}{|c|}{ Total abundance } & \multicolumn{2}{|c|}{ Elasmopus brasiliensis } & \multicolumn{2}{|c|}{$\begin{array}{l}\text { Elasmopus } \\
\text { pocillimanus }\end{array}$} & \multirow[t]{2}{*}{$F$ versus } \\
\hline & & MS & $\boldsymbol{P}$ & MS & $\boldsymbol{P}$ & MS & $P$ & MS & $\boldsymbol{P}$ & \\
\hline Habitat $=\mathrm{Ha}$ & 3 & 55.09 & $0.0001^{* * a}$ & 4091.94 & $0.0001^{* * a}$ & 2.11 & $0.0002^{* * a}$ & 1.0179 & $0.0312^{* \mathrm{a}}$ & $\mathrm{Ha} \times \mathrm{Si}$ \\
\hline Detritus $=$ De & 2 & 13.41 & 0.3754 & 292.03 & $0.4656^{\mathrm{b}}$ & 0.25 & $0.4311^{\mathrm{b}}$ & 0.1218 & $0.6934^{\mathrm{b}}$ & $\mathrm{De} \times \mathrm{Si}$ \\
\hline Site $=\mathrm{Si}$ & 1 & 14.01 & $0.0786^{\mathrm{a}}$ & 913.01 & $0.1238^{a, b}$ & 0.03 & $0.7750^{\mathrm{a}, \mathrm{b}}$ & 0.0991 & $0.5858^{\mathrm{a}, \mathrm{b}}$ & Res \\
\hline $\mathrm{Ha} \times \mathrm{De}$ & 6 & 3.89 & 0.8588 & 249.9 & 0.4604 & 0.19 & 0.8446 & 0.2362 & 0.5790 & $\mathrm{Ha} \times \mathrm{De} \times \mathrm{Si}$ \\
\hline $\mathrm{Ha} \times \mathrm{Si}$ & 3 & 2.09 & 0.7072 & 496.94 & 0.2782 & 0.01 & 0.9911 & 0.1183 & 0.7902 & Res \\
\hline $\mathrm{De} \times \mathrm{Si}$ & 2 & 8.06 & $0.1679^{a}$ & 85.73 & 0.7992 & 0.12 & 0.6709 & 0.2804 & 0.4406 & Res \\
\hline $\mathrm{Ha} \times \mathrm{De} \times \mathrm{Si}$ & 6 & 9.88 & $0.0466^{\mathrm{a}}$ & 229.6 & $0.7253^{\mathrm{a}, \mathrm{b}}$ & 0.45 & $0.1767^{\mathrm{a}, \mathrm{b}}$ & 0.2799 & $0.5387^{\mathrm{a}} \mathrm{b}$ & Res \\
\hline Residual & 96 & 4.51 & & 3381.55 & & 0.31 & & 0.3392 & & \\
\hline Cochran's C-test & & $C=0.145$ & & $C=0.652$ & $0.01)$ & $\mathrm{C}=0$. & ns & $C=0.13$ & & \\
\hline Transformation & & - & & - & & $\operatorname{Sqrt}(x$ & & $\operatorname{Ln}(x+1$ & & \\
\hline SNK & & Ha: $\mathrm{H}>\mathrm{C}$ & & Ha: $\mathrm{H}>\mathrm{C}$ & $=\mathrm{C}$ & Ha: $\mathrm{H}$ & $>\mathrm{C}>\mathrm{A}$ & Ha: $\mathrm{H}>$ & $\mathrm{C}>\mathrm{A}$ & \\
\hline \multirow[t]{2}{*}{ Source of variation } & \multirow[t]{2}{*}{ df } & \multicolumn{2}{|c|}{ Gammarella fucicola } & \multicolumn{2}{|c|}{ Caprella acanthifera } & \multicolumn{2}{|c|}{ Microdeutopus spp. } & \multicolumn{2}{|c|}{ Lyssianasa longicornis } & \multirow[t]{2}{*}{$F$ versus } \\
\hline & & MS & $\boldsymbol{P}$ & MS & $\boldsymbol{P}$ & MS & $\boldsymbol{P}$ & MS & $\boldsymbol{P}$ & \\
\hline Habitat $=\mathrm{Ha}$ & 3 & 1015.84 & $0.0029^{* a}$ & 1.47 & 0.4701 & 4.38 & 0.1801 & 4.05 & 0.1566 & $\mathrm{Ha} \times \mathrm{Si}$ \\
\hline Detritus $=$ De & 2 & 166.07 & $0.4461^{\mathrm{b}}$ & 0.29 & 0.7863 & 1.67 & 0.5523 & 0.96 & 0.345 & $\mathrm{De} \times \mathrm{Si}$ \\
\hline Site $=\mathrm{Si}$ & 1 & 116.03 & $0.4526^{\mathrm{a}, \mathrm{b}}$ & 7.79 & $0.0001^{* *}$ & 23.41 & $0.0001^{* *}$ & 0.95 & 0.0792 & Res \\
\hline $\mathrm{Ha} \times \mathrm{De}$ & 6 & 230.42 & 0.1855 & 0.49 & 0.5238 & 0.49 & 0.5661 & 0.65 & 0.0922 & $\mathrm{Ha} \times \mathrm{De} \times \mathrm{Si}$ \\
\hline $\mathrm{Ha} \times \mathrm{Si}$ & 3 & 158.46 & 0.5143 & 1.34 & $0.0392^{*}$ & 1.35 & $0.0294^{*}$ & 0.1 & $0.0149^{*}$ & Res \\
\hline $\mathrm{De} \times \mathrm{Si}$ & 2 & 174.56 & 0.4319 & 1.06 & 0.1064 & 2.07 & $0.0106^{*}$ & 0.51 & 0.1901 & Res \\
\hline $\mathrm{Ha} \times \mathrm{De} \times \mathrm{Si}$ & 6 & 106.68 & $0.7899^{a, b}$ & 0.51 & 0.3627 & 0.57 & 0.2583 & 0.2 & 0.6663 & Res \\
\hline Residual & 96 & 206.12 & & 0.46 & & 0.43 & & 0.3 & & \\
\hline Cochran's C-test & & \multicolumn{2}{|c|}{$C=0.8863(P<0.01)$} & \multicolumn{2}{|c|}{$\mathrm{C}=0.1524 \mathrm{~ns}$} & \multicolumn{2}{|c|}{$\mathrm{C}=0.1526 \mathrm{~ns}$} & \multicolumn{2}{|c|}{$\mathrm{C}=0.1527 \mathrm{~ns}$} & \\
\hline Transformation & & \multicolumn{2}{|c|}{-} & \multicolumn{2}{|c|}{$\operatorname{Sqrt}(x+1)$} & \multicolumn{2}{|c|}{$\operatorname{Sqrt}(x+1)$} & \multicolumn{2}{|c|}{$\operatorname{Ln}(x+1)$} & \\
\hline SNK & & \multicolumn{2}{|c|}{ Ha: $\mathrm{H}>\mathrm{Ca}=\mathrm{A}=\mathrm{C}$} & \multicolumn{2}{|c|}{$\begin{array}{l}\mathrm{Ha} \times \text { Si: } 1: A>H= \\
\mathrm{Ca}=\mathrm{C} \\
2: \mathrm{H}=\mathrm{Ca}=\mathrm{A}=\mathrm{C}\end{array}$} & \multicolumn{2}{|c|}{$\begin{array}{l}\mathrm{Ha} \times \mathrm{Si}: 1: H= \\
\mathrm{Ca}>\mathrm{A}=\mathrm{C} \\
2: \mathrm{Ca}>\mathrm{H}=\mathrm{A}=\mathrm{C} \\
\mathrm{De} \times \mathrm{Si}: 1: \mathrm{H}>\emptyset=\mathrm{L} \\
2: \emptyset=\mathrm{L}=\mathrm{H}\end{array}$} & \multicolumn{2}{|c|}{$\begin{array}{l}\mathrm{Ha} \times \mathrm{Si}: 1: \mathrm{H}>\mathrm{Ca}= \\
\mathrm{A}=\mathrm{C}\end{array}$} & \\
\hline
\end{tabular}

values of amphipod species richness and abundance but with high spatial heterogeneity of these attributes. H. scoparia beds have a high structural complexity, and seem to serve as an important habitat for amphipod assemblages, as shown by the very high values of species richness and abundance recorded for amphipods in the present study. Artificial substrata provide a refuge for amphipods, but natural vegetated 
Malta
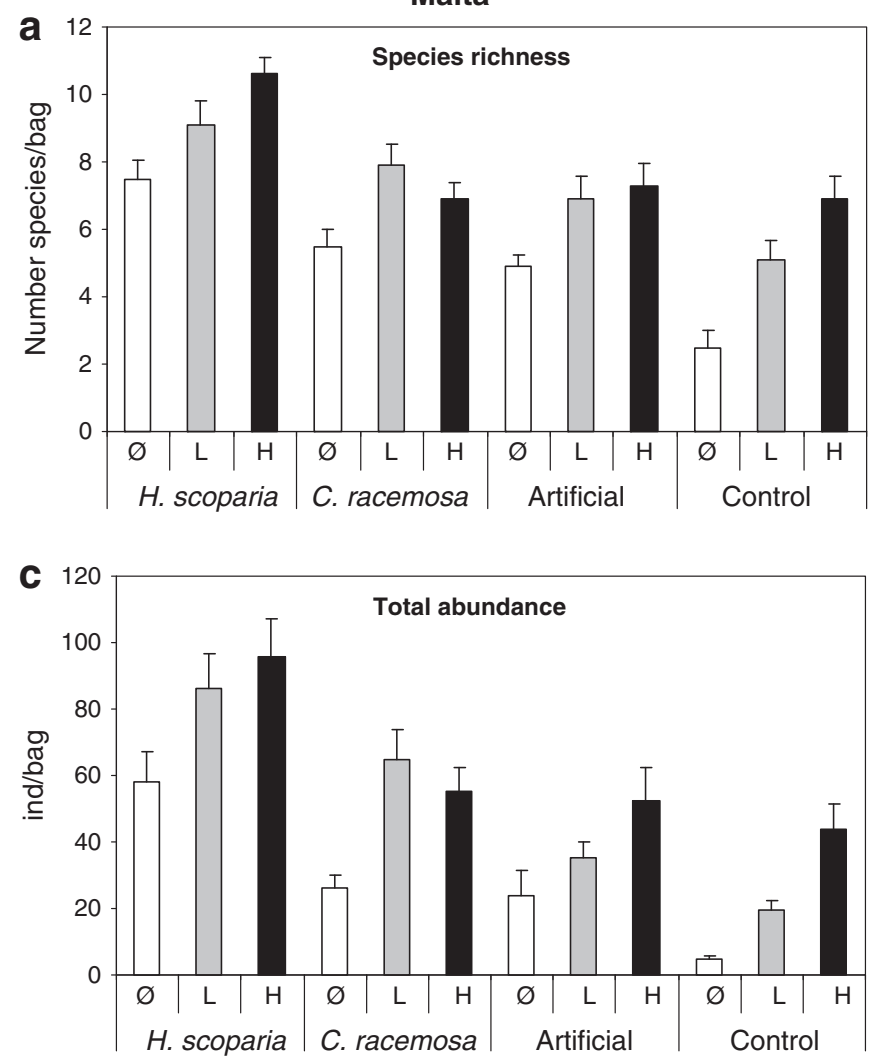

Spain
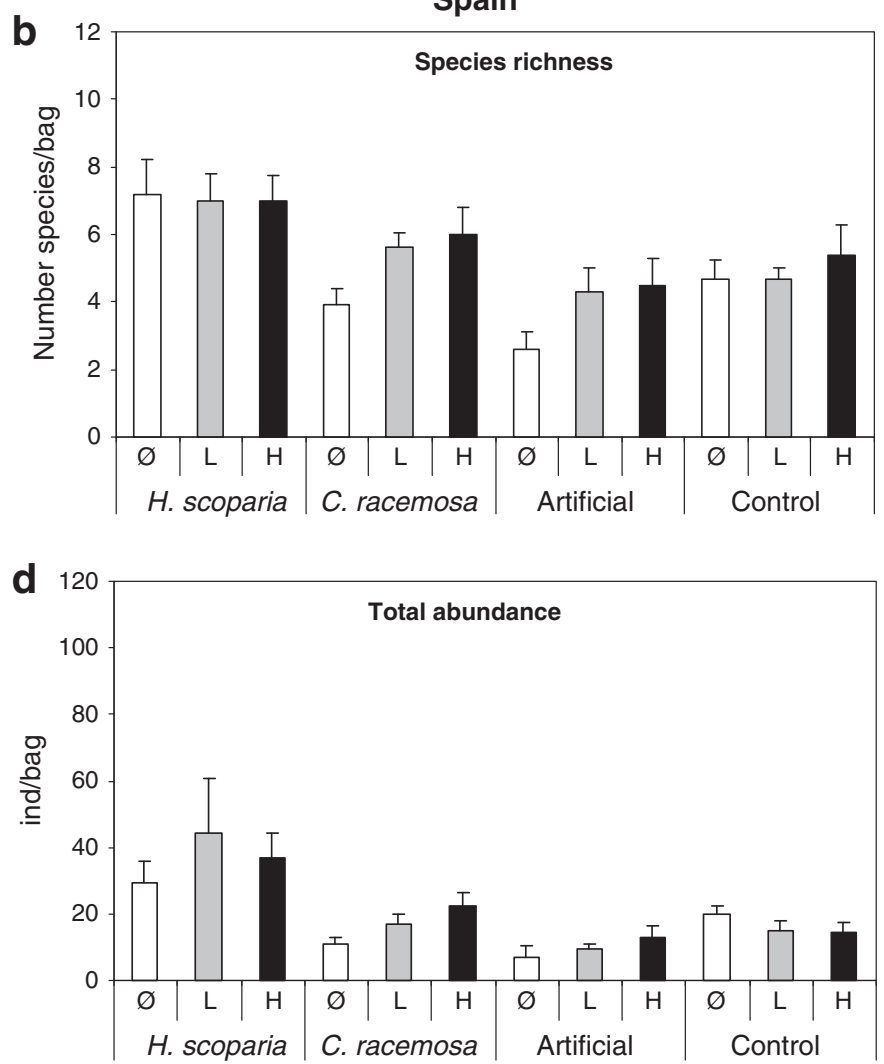

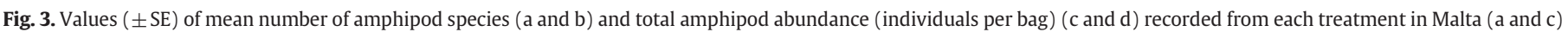
and Spain (b and d).

habitats are more attractive for the fauna. Some differences in the responses of amphipods were noted at the regional and local scale. However, such variation in the amphipods' response would be expected. Many studies have shown that the largest sources of spatial and temporal variability in the abundance of benthic organisms often occur at the smallest scales (Fraschetti et al., 2005), and this would be related to a number of biotic and abiotic variables. Such factors vary and interact at both the small spatial and temporal scales and may influence important habitat features such as detritus present.

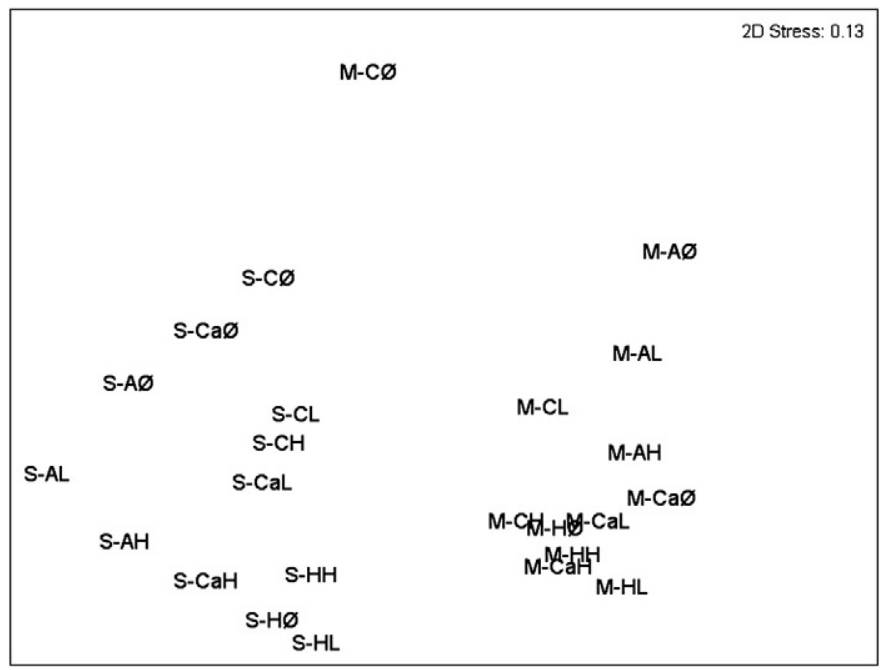

Fig. 4. Two-dimensional MDS plot for amphipod species abundance. $M=$ Malta; $S=S p a i n$; $\mathrm{H}=$ H. scoparia; $\mathrm{Ca}=$ C. racemosa; $\mathrm{A}=$ artificial; $\mathrm{C}=$ control; $\varnothing=$ without detritus; $\mathrm{L}=$ low detritus and $\mathrm{H}=$ high detritus content.
In general, three main processes may account for faunal distribution patterns. One is different rates of settlement/recruitment; larvae or juveniles can recruit in larger numbers in one habitat compared to others (Dayton, 1975; Moore and Lopez, 1972). However, for peracarid crustaceans, it can indicate that juvenile amphipods may be actively seeking new habitats that have lower faunal abundance, thereby, avoiding competition with adults. An alternative explanation is that amphipod populations are distributed randomly in the available habitats but differential mortality leads to reduction in numbers in unfavourable habitats (Levins, 1968; Russo, 1987). Furthermore, previous studies have demonstrated that predation rates on amphipods differ depending on

Table 2

Results of the multivariate analyse PERMANOVA for amphipod assemblage. MS = mean square; $P=$ level of significance; $\mathrm{df}=$ degrees of freedom; ${ }^{*}=$ significant $(P<0.05),{ }^{* *}=$ significant $(P<0.01)$.

\begin{tabular}{lllll}
\hline Source of variation & df & \multicolumn{2}{l}{ Amphipod assemblage } & \multirow{2}{*}{ F versus } \\
\cline { 3 - 4 } & & MS & $P$ & \\
\hline Locality $=$ Lo & 1 & 89690.63 & $0.0010^{* *}$ & Si (Lo) \\
Habitat $=$ Ha & 3 & 13356.26 & 0.1320 & Lo $\times$ Ha \\
Detritus $=$ De & 2 & 3197.98 & 0.9080 & Lo $\times$ De \\
Site $=$ Si (Lo) & 2 & 3126.08 & $0.0160^{*}$ & Res \\
Lo $\times$ Ha & 3 & 7827.47 & $0.0010^{* *}$ & Ha $\times$ Si (Lo) \\
Lo $\times$ De & 2 & 6600.17 & 0.3850 & De $\times$ Si (Lo) \\
Ha $\times$ De & 6 & 2521.15 & 0.8280 & Lo $\times$ Ha $\times$ De \\
Ha $\times$ Si (Lo) & 6 & 1557.43 & 0.5050 & Res \\
De $\times$ Si (Lo) & 4 & 5882.81 & $0.0010^{* *}$ & Res \\
Lo $\times$ Ha $\times$ De & 6 & 3351.99 & 0.1600 & Ha $\times$ De $\times$ Si (Lo) \\
Ha $\times$ De $\times$ Si (Lo) & 12 & 2621.91 & $0.0010^{* *}$ & Res \\
Residual & 192 & 1583.72 & & \\
Transformation & Fourth root & & \\
\hline
\end{tabular}

Post-hoc test $($ Lo $\times$ Ha) : Malta: $H$. scoparia $\neq$ C. racemos $a=$ Control $\neq$ Artificial. Spain: H. scoparia $\neq$ C. racemos $a \neq$ Control $=$ Artificial. 
Malta
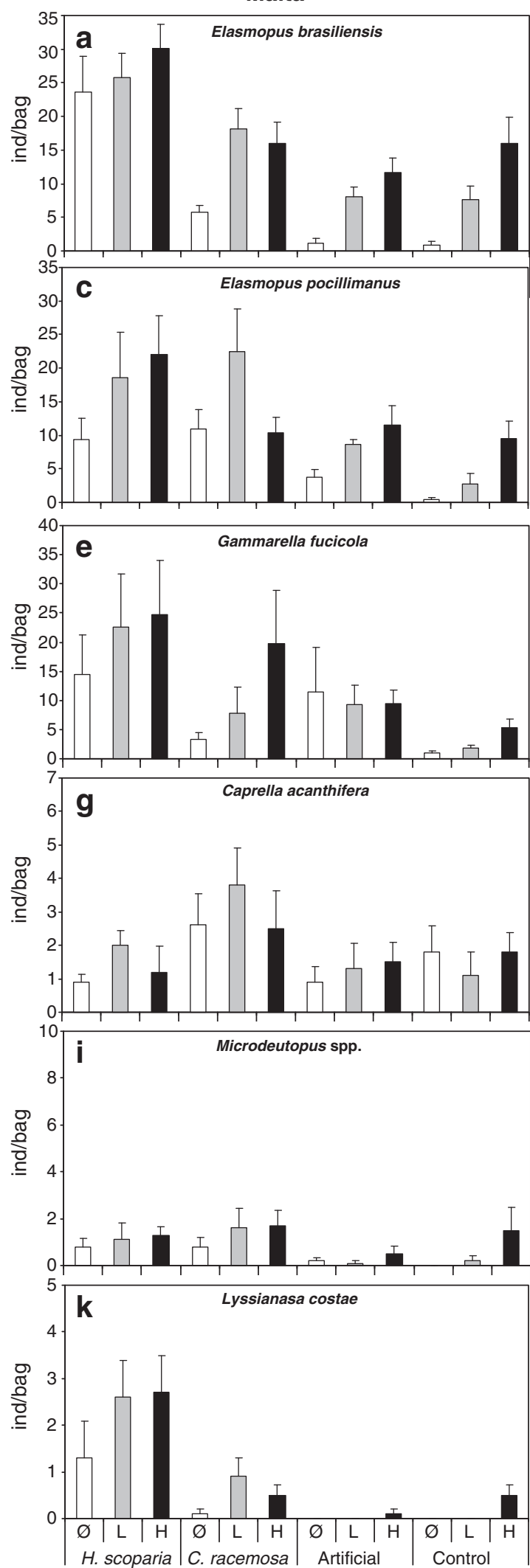

Spain
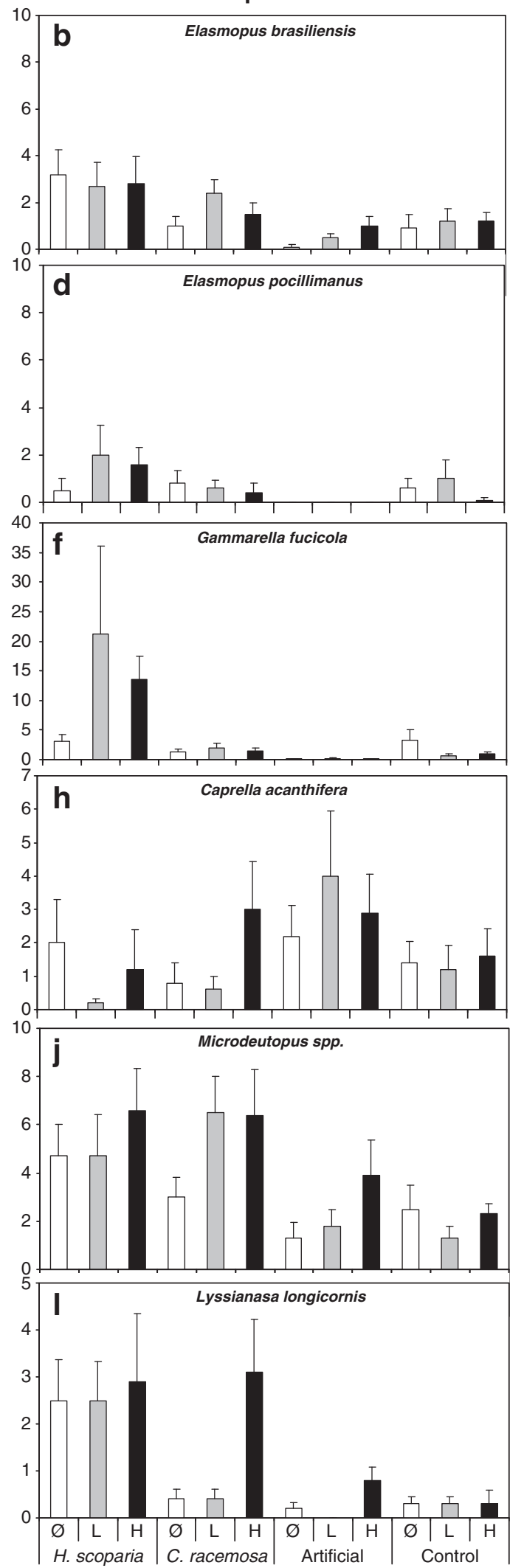

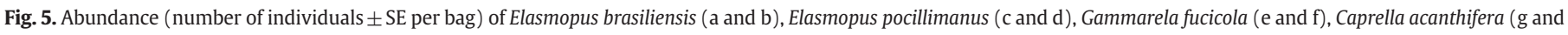

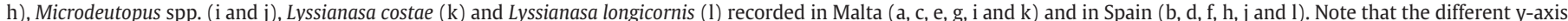
scale of plots for Elasmopus brasiliensis and Elasmopus pocillimanus. 
species and on the habitat with which they associate (Poore, 2004; Vázquez-Luis et al., 2010). A third alternative is that following recruitment of juveniles, adults select favoured habitats (Crowe and Underwood, 1998). It has been demonstrated that amphipods can actively choose substrata and show high habitat fidelity (Poore and Hill, 2006; Roberts and Poore, 2005; Stoner, 1980). In our study, amphipods seem to prefer $H$. scoparia compared to the other habitats; however, since such processes are not exclusive, a combination of other factors and processes may also affect the observed patterns of distribution of amphipods.

Several studies highlight the importance of habitat structural complexity in determining the abundance and species richness of associated mobile epifauna (Beck, 2000; Chemello and Milazzo, 2001; Grabowski and Powers, 2004; Martin-Smith, 1993; Orth et al., 1984). The present results show that some amphipod species have a higher abundance in specific habitats. Some species (E. brasiliensis, G. fucicola, L. costae and $L$. longicornis) were associated with $H$. scoparia possibly because of the higher structural complexity of this alga. The importance of habitat physical structure compared with other features, such as chemical cues or micro-fouling as food resource, may be high because the artificial substratum used in our experiment had a higher abundance of some species. It should also be noted that the mesh per se serves as an ideal substratum for the attachment of caprellids using their pereiopods, while amphipods belonging to this group are also predominantly found attached to the more exposed parts of plants (Aoki, 1999; Sudo and Azeta, 2001). C. acanthifera was consistently present in the mesh bags and the species has been reported to occur on many different substrata (see Guerra-García, 2001).

C. racemosa does not appear to be an unfavourable substratum for amphipods. E. pocillimanus and Microdeutopus spp. were more abundant in $H$. scoparia and C. racemosa. Moreover, species of the genus Microdeutopus are reported to have higher abundance values on substrata colonised by $C$. racemosa compared to ones colonised by native algae (Vázquez-Luis et al., 2008, 2009b). In contrast, C. acanthifera had different patterns of abundance at the two localities; in Malta it was more abundant in C. racemosa habitat, while in Spain it was more abundant on the artificial substratum.

Our results show that the species richness and abundance of amphipods may be affected by the presence of detritus but with high spatial heterogeneity. Detritus plays a very important role as a trophic resource for marine invertebrates and serves as one of the main trophic pathways in marine ecosystems (Valiela, 1995), while it is also one of the most important features of habitat structure in vegetated habitats (Allesina et al., 2005). It is suggested that amphipods do not consume algal biomass directly, but feed on associated material such as detritus (Enequist, 1949). The detritus stock associated with C. racemosa appears to play an important role for amphipod assemblages, as has been shown in other studies (Vázquez-Luis et al., 2008). It appears that gammarids are able to exploit the detritus as a microhabitat, while this is not as useful for caprellids which prefer the external canopy (Aoki, 1999) but Guerra-García and Tierno de Figueroa (2009) showed that detritus was clearly the main dietary component of caprellids.

Some species were abundant in their natural habitat but were absent in the mesh bags. One explanation is that the biology of a given species may be playing an important role. Herbivorous amphipods, such as those belonging to the family Ampithoidae and the genera Hyale and Dexamine, had high abundance values in their natural habitat but lower abundance values in the mesh bags at both study localities. Some species such as $A$. ramondi, $D$. spiniventris, $H$. camptonyx and $H$. schmidti are strongly linked to the algal canopy and are very sensitive to habitat alteration; hence, they did not respond under experimental conditions. A. ramondi lives in transparent, gelatinous tubes on algae and seagrasses (Ruffo, 1982) and is therefore a sedentary species that does not move away from its host. In any case, lower abundance values of $A$. ramondi and $H$. schmidti in habitats invaded by
C. racemosa and $C$. prolifera have been detected in some studies (Sánchez-Moyano et al., 2001; Vázquez-Luis et al., 2008, 2009b). Another possible explanation concerns the limitation of the methodology used in our experiment, since algae placed in our experimental bags did not necessarily retain the same morphology, and hence structural complexity, compared to the erect algae attached to the substratum in the natural habitat. However, in spite of this, the use of an appropriate experimental design to avoid confounding influences in studies of habitat selection as adopted in the present work is deemed very important (Olabarria et al., 2002).

In conclusion, when introduced, $C$. racemosa modifies rocky bottom algal habitats, which results in changes to the abundance and species richness of the associated amphipod assemblages. However, some amphipods fare better in algal habitat that has been invaded by the alien species. The present findings suggest that the total abundance and species richness of amphipods is higher in algal stands formed by the native $H$. scoparia but is also positively affected by the presence $C$. racemosa. Detritus may play an important role, depending on local environmental factors, since colonization of invertebrates is a complex process and local ecological conditions may also be very important in determining substratum selection by amphipods. Further experiments on habitat selection and the diet of amphipods are necessary to obtain a better understanding of such potential changes to benthic ecosystem functioning that may result from the spread of invasive species.

\section{Acknowledgements}

We are very grateful to Ecoserv Ltd (Malta) for making its facilities available, and to staff of the same company, in particular, Sarah Gauci Carlton, for their assistance. We thank Redsinsa S.A. for providing the mesh and Pablo Arechavala-López for his assistance during field work. We are also grateful to the Director of the Park of Sierra Helada, Benidorm (Spain), Dr. Eduardo Mínguez, and wardens of the park, for their support and assistance during fieldwork. Special thanks are also due to Prof. Anthony Underwood for his valuable advice. This work was supported by Instituto Alicantino de Cultura Juan Gil Albert, Excma. Diputación de Alicante and by a research grant awarded by the University of Malta to J. A. Borg. [ST]

\section{References}

Allesina, S., Bondavalli, C., Scharler, U.M., 2005. The consequences of the aggregation of detritus pools in ecological networks. Ecol. Model. 189, 221-232.

Anderson, M.J., 2001. A new method for non-parametric multivariate analysis of variance. Austral Ecol. 26, 32-46.

Aoki, M., 1999. Morphological characteristics of young, maternal care behaviour and microhabitat use by caprellid amphipods. J. Mar. Biol. Assoc. U. K. 79, 629-638.

Argyrou, M., Demetropoulos, A., Hadjichristophorou, M., 1999. Expansion of the macroalga Caulerpa racemosa and changes in softbottom macrofaunal assemblages in Moni Bay, Cyprus. Oceanol. Acta 22, 517-528.

Beare, D.J., Moore, P.G., 1997. The contribution of Amphipoda to the diet of certain inshore fish species in Kames Bay, Millport. J. Mar. Biol. Assoc. U. K. 77, 907-910.

Beck, M.W., 2000. Separating the elements of habitat structure: independent effects of habitat complexity and structural components on rocky intertidal gastropods. J. Exp. Mar. Biol. Ecol. 249, 29-49.

Bellan-Santini, D., 1980. Relationship between populations of amphipods and pollution. Mar. Pollut. Bull. 11, 224-227.

Brawley, S.H., 1992. Mesoherbivores. In: John, D.M., Hawkins, S.J., Price, J.H. (Eds.), Plantanimal interactions in the marine benthos. Clarendon Press, Oxford, UK, pp. 235-263.

Cannon, J.F.M., 1979. An experimental investigation of Posidonia balls. Aquat. Bot. 6, 407-410.

Carrasco, F.D., Arcos, D.F., 1984. Life history of a cold temperate population of the sublittoral amphipod Ampelisca araucana. Mar. Ecol. Prog. Ser. 14, 245-252.

Cavas, L., Baskin, Y., Yurdakoc, K., Olgun, N., 2006. Antiproliferative and newly attributed apoptotic activities from an invasive marine alga: Caulerpa racemosa var. cylindracea. J. Exp. Mar. Biol. Ecol. 339, 111-119.

Chemello, R., Milazzo, M., 2001. Effect of algal architecture on associated fauna: some evidence from phytal molluscs. Mar. Biol. 140, 981-990.

Clarke, K.R., Warwick, R.M., 1994. Changes in Marine Communities: an approach to statistical analysis and interpretation. Natural Environment Research Council, UK. 144 pp. 
Conradi, M., López-González, P.J., García-Gómez, J.C., 1997. The amphipod community as a bioindicator in Algeciras Bay (Southern Iberian Peninsula) based on a spatiotemporal distribution. Mar. Ecol. 18, 97-111.

Crooks, J.A., 2002. Characterizing ecosystem-level consequences of biological invasions: the role of ecosystem engineers. Oikos 97, 153-166.

Crowe, T.P., Underwood, A.J., 1998. Testing behavioural "preference" for suitable microhabitat. J. Exp. Mar. Biol. Ecol. 225, 1-11.

Dayton, P.K., 1975. Experimental evaluation of ecological dominance in a rocky intertidal community. Ecol. Monogr. 45, 137-159.

Enequist, P., 1949. Studies on the soft bottoms amphipods of the Shaggerak. Zool. Bidr. Upps. 28, 297-492

Fraschetti, S., Terlizzi, A., Benedetti-Cecchi, L., 2005. Patterns of distribution of marine assemblages from rocky shores: evidence of relevant scales of variation. Mar. Ecol. Prog. Ser. 296, 13-29.

Grabowski, J.H., Powers, S.P., 2004. Habitat complexity mitigates trophic transfer on oyster reefs. Mar. Ecol. Prog. Ser. 277, 291-295.

Guerra-García, J.M., 2001. Habitat use of the Caprellidea (Crustacea: Amphipoda) from Ceuta, North Africa. Ophelia 55, 27-38.

Guerra-García, J.M., Tierno de Figueroa, J.M., 2009. What do caprellids (Crustacea: Amphipoda) feed on? Mar. Biol. 156, 1881-1890.

Highsmith, R.C., Coyle, K.O., 1990. High productivity of northern Bering Sea benthic amphipods. Nature 344, 862-864.

Koukouras, A., Russo, A., Voultsiadoukoukoura, E., Dounas, C., Chintiroglou, C., 1992. Relationship of sponge macrofauna with the morphology of their hosts in the north Aegean Sea. Int. Rev. Ges. Hydrobiol. 77, 609-619.

Levins, R., 1968. Evolution in changing environments: some theoretical explorations. Princeton University Press, Princeton, NJ.

Martin-Smith, K.M., 1993. Abundance of mobile epifauna: the role of habitat complexity and predation by fishes. J. Exp. Mar. Biol. Ecol. 174, 243-260.

Moore, H.B., Lopez, N.N., 1972. Factors controlling variation in the seasonal spawning pattern of Lytechinus variegatus. Mar. Biol. 14, 275-280.

Olabarria, C., Underwood, A.J., Chapman, M.G., 2002. Appropriate experimental design to evaluate preferences for microhabitat: an example of preferences by species of microgastropods. Oecologia 132, 159-166.

Orth, R.J., Heck, K.L., von Montfrans, J., 1984. Faunal communities in seagrass beds: a review of the influence of plant structure and prey characteristics on predator-prey relationships. Estuaries 7, 339-350.

Piazzi, L., Balata, D., 2008. The spread of Caulerpa racemosa var. cylindracea in the Mediterranean Sea: an example of how biological invasions can influence beta diversity. Mar. Environ. Res. 65, 50-61.

Poore, A.G.B., 2004. Spatial associations among algae affect host use in a herbivorous marine amphipod. Oecologia 140, 104-112.

Poore, A.G.B. Hill, N.A. 2006. Sources of variation in herbivore preference: among individual and past diet effects on amphipod host choice. Mar. Biol. 149, 1403-1410.

Roberts, D.A., Poore, A.G.B., 2005. Habitat configuration affects colonisation of epifauna in marine alga bed. Biol. Conserv. 127, 18-26.

Ruffo, S. (Ed.), 1982. The Amphipoda of the Mediterranean. Part 1, Gammaridea: Mémoires de l'Institut Océanographique, Monaco, 13. 364 pp.

Ruitton, S., Verlaque, M., Boudouresque, C.F., 2005. Seasonal changes of the introduced Caulerpa racemosa var. cylindracea (Caulerpales, Chlorophyta) at the northwest limit of its Mediterranean range. Aquat. Bot. 82, 55-70.

Russo, A.R., 1987. Role of habitat complexity in mediating predation by the gray damselfish Abedefduf sordidus on epiphytal amphipods. Mar. Ecol. Prog. Ser. 36, 101-105.

Sanchez-Jerez, P., Barberá-Cebrián, C., Ramos-Esplá, A.A., 1999. Comparison of the epifauna spatial distribution in Posidonia oceanica, Cymodocea nododa and unvegetated bottoms: importance of meadow edges. Acta Oecol. 20, 391-405.
Sanchez-Jerez, P., Barberá -Cebrián, C., Ramos-Esplá, A.A., 2000. Influence of the structure of Posidonia oceanica meadows modified by bottom trawling on crustacean assemblages: comparison of amphipods and decapods. Sci. Mar. 64, 319-326.

Sánchez-Moyano, J.E., Estacio, F.J., García-Adiego, E.M., García-Gómez, J.C., 2001. Effect of the vegetative cycle of Caulerpa prolifera on the spatio-temporal variation of invertebrate macrofauna. Aquat. Bot. 70, 163-174.

Sarvala, J., Uitto, A., 1991. Production of the benthic amphipod Pontoporeia affinis and $P$. femorata in a Baltic archipielago. Ophelia 34, 71-90.

Schmidt-Nielson, K., 1984. Scaling: why is animal size so important? Cambridge University Press, Cambridge.

Schmidt, A.L., Scheibling, R.E., 2007. Effects of native and invasive macroalgal canopies on composition and abundance of mobile benthic macrofauna and turf-forming algae. J. Exp. Mar. Biol. Ecol. 341, 110-130.

Sebens, K.P., 1991. Habitat structure and community dynamics in marine benthic systems. Cap. 11, 211-234 pp. In: Bell, Susan S., McCoy, Earl D., Mushinsky, Henry R (Eds.), Habitat structure. The physical arrangement of objects in space. Department of Biology, University of Florida.

Stål, J., Pihl, L., Wennhage, H., 2007. Food utilisation by coastal fish assemblages in rocky and soft bottoms on the Swedish west coast: inference for identification of essential fish habitats. Estuar. Coast. Shelf Sci. 71, 593-607.

Stoner, A.W., 1979. Species specific predation on amphipod Crustacea by the pinfish Lagodon rhomboides: mediation by macrophyte standing crop. Mar. Biol. 55, 201-208.

Stoner, A.W., 1980. Perception and choice of substratum by epifaunal amphipods associated with seagrasses. Mar. Ecol. Prog. Ser. 3, 105-111.

Sudo, H., Azeta, M., 2001. The microhabitat and size of gammarid species selectively predated by young red sea bream Pagrus major. Fish. Sci. 67, 389-400.

Underwood, A.J., 1981. Techniques of analysis of variance in experimental biology and ecology. Oceanogr. Mar. Biol. Annu. Rev. 19, 513-605.

Underwood, A.J., 1997. Experiments in Ecology: Their Logical Design and Interpretation Using Analysis of Variance. Cambridge University Press. 504 pp.

Valiela, I., 1995. Marine Ecological Processes. Springer-Verlag, New York. 686 pp.

Vázquez-Luis, M., Sanchez-Jerez, P., Bayle-Sempere, J.T., 2008. Changes in amphipod (Crustacea) assemblages associated with shallow-water algal habitats invaded by Caulerpa racemosa var. cylindracea in the western Mediterranean Sea. Mar. Environ. Res. 65, 416-426.

Vázquez-Luis, M., Guerra-García, J.M., Sanchez-Jerez, P., Bayle-Sempere, J.T., 2009a. Caprellid assemblages (Crustacea: Amphipoda) in shallow waters invaded by Caulerpa racemosa var. cylindracea from southeastern Spain. Helgol. Mar. Res. 63 107-117.

Vázquez-Luis, M., Sanchez-Jerez, P., Bayle-Sempere, J.T., 2009b. Comparison between amphipod assemblages associated with Caulerpa racemosa var. cylindracea and those of other Mediterranean habitats on soft substrate. Estuar. Coast. Shelf Sci. 84, 161-170.

Vázquez-Luis, M., Sanchez-Jerez, P., Bayle-Sempere, J.T., 2010. Effects of Caulerpa racemosa var. cylindracea on prey availability: an experimental approach to predation by Thalassoma pavo (Labridae) on amphipods. Hydrobiologia 654, 147-154.

Virnstein, R.W., 1987. Seagrass-associated invertebrate communities of the Southeastern USA: a review. Florida Marine Research Publications, 42, pp. 89-116.

Vitousek, P.M., 1990. Biological invasions and ecosystem processes: towards an integration of population biology and ecosystem studies. Oikos 57, 7-13.

Wikström, S.A., Kautsky, L., 2004. Invasion of a habitat-forming seaweed: effects on associated biota. Biol. Invasion 6, 141-150.

Williams, S.L., Smith, J.E., 2007. A global review of the distribution, taxonomy, and impacts of introduced seaweeds. Annu. Rev. Ecol. Evol. Syst. 38, 327-359.

Williamson, M.H., Fitter, A., 1996. The varying success of invaders. Ecology 77 (6), 1661-1666. 